\title{
IMPLEMENTASI STRATEGI REACT TERHADAP HASIL BELAJAR DAN KETERAMPILAN SOSIAL PESERTA DIDIK
}

\author{
Hafizatul Maulida ${ }^{1}$., Syahmani ${ }^{2}$, Mella Mustika Sari ${ }^{3}$ \\ ${ }^{1}$ Prodi Pendidikan IPA FKIP Universitas Lambung Mangkurat, Banjarmasin, Indonesia \\ e-mail: hafizatulmaulida@gmail.com \\ ${ }^{2}$ Prodi Pendidikan Kimia FKIP Universitas Lambung Mangkurat, Banjarmasin, Indonesia \\ e-mail: syahmani_kimia@ulm.ac.id \\ ${ }^{3}$ Prodi Pendidikan IPA FKIP Universitas Lambung Mangkurat, Banjarmasin, Indonesia \\ e-mail: mella.science.edu@ulm.ac.id
}

\begin{abstract}
Submit: 08-06-2020 Revisi: 07-07-2020 Diterima: 08-07-2020 Diterbitkan: 17-08-2020
\end{abstract}
\begin{abstract}
Abstrak: Penelitian ini bertujuan untuk mengetahui signifikansi dari dampak implementasi strategi pembelajaran REACT terhadap hasil belajar dan keterampilan sosial peserta didik. Penelitian ini menerapkan metode kuasi eksperimental dengan menggunakan pre-test post-test nonequivalent control group design. Teknik pengambilan sampel yang digunakan yaitu porpusive sampling. Sampel penelitian yaitu peserta didik kelas VII D SMPN 13 Banjarmasin terdiri dari 25 orang sebagai kelas eksperimen dan peserta didik kelas VII A terdiri dari 29 orang sebagai kelas kontrol. Teknik pengumpulan data menggunakan tes dan observasi. Teknik analisis menggunakan uji independent dan paired sampel $t$-test untuk data hasil belajar. Uji Kruskall-Wallis dan uji urutan bertanda Wilcoxon untuk data keterampilan sosial, dan juga analisis deskriptif. Hasil penelitian menunjukkan bahwa (1) ada perbedaan hasil belajar yang signifikan antara kelas ekperimen dengan kelas kontrol dengan nilai signifikansi 0,03 ; (2) ada peningkatan hasil belajar peserta didik menggunakan strategi $R E A C T$ dengan nilai $n$-gain 0,6 (sedang) dan nilai signifikansi 0,00 ; (3) ada perbedaan keterampilan sosial peserta didik antara penerapan strategi pembelajaran REACT dengan pembelajaran konvensional dengan nilai signifikansi 0,00; dan (4) ada peningkatan keterampilan sosial peserta didik menggunakan strategi REACT dengan nilai signifikansi 0,00. Dengan demikian, implementasi strategi pembelajaran $R E A C T$ berdampak signifikan terhadap hasil belajar dan keterampilan sosial peserta didik.
\end{abstract}

Kata kunci: Hasil Belajar, Keterampilan Sosial, Pencemaran Lingkungan, Strategi REACT

\section{IMPLEMENTATION OF THE REACT STRATEGY ON LEARNING OUTCOMES AND STUDENTS' SOCIAL SKILLS}

\begin{abstract}
This study aims to determine the significance of the impact of REACT learning strategy implementation on learning outcomes and students' social skills. This study applied the quasi-experimental method using a pretest-posttest nonequivalent control group design. The sampling technique used is a porous sampling. The sample of the study was students of class VII D SMPN 13 Banjarmasin consisting of 25 people as the experimental class and students of class VII A SMPN 13 Banjarmasin consisted of 29 people as the control class. Data collection techniques use tests and observation techniques. The analysis technique uses independent tests and paired-samples t-test for knowledge learning outcomes data. The Kruskal-Wallis test and the Wilcoxon sequence test for social skills data, and also descriptive analysis. The results showed that: (1 there is a significant difference in learning outcomes between the experimental class and the control class with a sig. $=0.03$; (2) there is an increase in students' learning outcomes using the REACT strategy with an n-gain value of 0.6 (moderate) and a value of significance 0.00; (3) there are differences in students' social skills between the application of REACT strategies with conventional learning with a sig. $=0.00$; and (4) there is an increase in students' so-
\end{abstract}


Maulida, Syahmani, \& Sari. (2020). Implementasi Strategi REACT Terhadap Hasil Belajar dan Keterampilan Sosial Peserta Didik

cial skills use the REACT strategy with a sig. $=0.00$. Thus, the implementation of the REACT learning strategy has a significant impact on student learning outcomes and social skills.

Keywords: Learning Outcomes, Social Skills, Environmental Pollution, REACT Strategy

\section{PENDAHULUAN}

Keterampilan dasar setiap individu untuk mampu bermasyarakat, berbangsa dan bernegara adalah dengan memiliki keterampilan sosial yang baik. Namun, dewasa ini sering terjadi perilaku yang kurang baik yang terlihat jelas dan nyata akan kemerosotan moral pelajar zaman sekarang (Fahmi, 2014). Contohnya mulai hilangnya budaya sopan santun seperti menyapa, cara bicara, berjalan melewati kerumunan, dan saat berpapasan dengan guru. Oleh karena itu, keterampilan sosial perlu dimiliki peserta didik agar mereka mudah berinteraksi, bersosialisasi, dan mempengaruhi keberhasilan dalam pembelajaran (Thalib, 2010). Namun, Hamdani (2010) menemukan masih banyak peserta didik yang keterampilan sosialnya masih rendah. Hal ini akibat dari pembelajaran yang tidak melibatkan peserta didik secara aktif. Pembelajaran selama ini belum menuntut peserta didik untuk dapat bekerjasama dalam kegiatan belajar mengajar dan belum melatih menyampaikan ide-ide serta pendapatnya karena pembelajaran yang cenderung monoton dari guru (Putri \& Santosa, 2015; Fahmi, 2016). Hal ini menjadikan hasil belajar peserta didik masih rendah, khususnya dalam mata pelajaran IPA (Sugiarti, 2015). Temuan ini diperkuat data Pamer UN 2018, rata-rata hasil UN mata pelajaran IPA secara nasional sebesar 51,76 dan SMPN 13 Banjarmasin memiliki nilai rata-rata UN 44,19 untuk mata pelajaran IPA.

Permasalahan rendahnya hasil belajar dan keterampilan sosial peserta didik perlu diatasi melalui inovasi pembelajaran. Inovasi pembelajaran yang akan digunakan peneliti adalah menerapkan strategi $R e-$ lating, Experiencing, Applying, Cooperating, Transfering (REACT). Strategi REACT adalah implementasi dari pendekatan pembelajaran kontekstual yang melibatkan peserta didik secara aktif melalui tahaptahapannya (Ismawati, 2017). Strategi REACT efektif dalam membantu guru IPA dan dapat mempertahankan konsepsi yang peserta didik peroleh dalam ingatan jangka panjang (Karsli, 2017; Ultay, 2016). Selain itu, strategi REACT berpengaruh secara signifikan terhadap hasil belajar peserta didik (Cahyono, 2017).

Strategi REACT memiliki cooperating stage yang dapat diterapkan pembelajaran kooperatif untuk melatih keterampilan sosial peserta didik. Pembelajaran kooperatif mendorong keaktifan, kemandirian, berpartisipasi, dan tanggung jawab dalam diri peserta didik (Abidin, 2016). Pembelajaran kooperatif juga dapat meningkatan keterampilan sosial peserta didik (Sarimaya, 2013). Implementasi strategi REACT diharapkan mampu mempengaruhi hasil belajar dan keterampilan sosial peserta didik lebih baik. Dalam penelitian ini, peneliti ingin menerapkan strategi $R E A C T$ di SMP pada materi pencemaran lingkungan.

\section{METODE PENELITIAN}

Rancangan penelitian ini adalah nonequivalent control group design dengan metode kuasi eksperimen (eksperimen semu). Penelitian dilaksanakan di bulan Maret 2019. Populasi penelitian ini adalah siswa kelas VII SMP 13 Kota Banjarmasin tahun ajaran 2018/2019, dengan sampel yaitu 2 kelas dari total 7 kelas. Teknik sampling yang digunakan adalah purposive sampling. Instrumen yang digunakan dalam penelitian ini yaitu tes hasil belajar dan lembar observasi keterampilan sosial. Selanjutnya, data hasil belajar peserta didik dapat dianalisis dengan uji-t berbantuan SPSS 23. Penskoran hasil belajar adalah (skor yang diperoleh/skor maksimal) $\mathrm{x}$ bobot soal. Adapun kriteria yang digunakan untuk memberikan kategori tingkat hasil tes belajar peserta didik disajikan pada Tabel 1.

Tabel 1. Kategori tingkat hasil tes belajar pengetahuan

\begin{tabular}{cl}
\hline Hasil Belajar (\%) & \multicolumn{1}{c}{ Kategori } \\
\hline$>90$ & Sangat baik \\
$81-90$ & Baik \\
$70-80$ & Cukup \\
$<70$ & Kurang \\
\hline & (Kemendikbud, 2017)
\end{tabular}

Data keterampilan sosial dianalisis melalui uji Kruskall-Wallis berbantuan SPSS 23 untuk mengukur perbedaan keterampilan sosial peserta didik di kelas eksperimen dengan kelas kontrol dan 
uji Wilcoxon untuk mengukur peningkatan keterampilan sosial peserta didik sebelum dan sesudah perlakuan. Penskoran keterampilan sosial adalah (jumlah skor diperoleh/jumlah skor maksimal) x 100 . Nilai persentase yang diperoleh kemudian dikategorikan sesuai Tabel 2.

Tabel 2. Kategori penilaian sikap

\begin{tabular}{cl}
\hline Rentang Skor (\%) & \multicolumn{1}{c}{ Kriteria } \\
\hline $84,25-100$ & Sangat baik \\
$59,25-83,25$ & Baik \\
$33,25-58,25$ & Cukup \\
$<33,25$ & Kurang \\
\hline & (Kemendikbud, 2017)
\end{tabular}

\section{HASIL DAN PEMBAHASAN}

\section{Hasil Belajar Peserta Didik}

Data hasil belajar peserta didik diperoleh melalui pre-test dan post-test. Kedua data ini diuji normalitas dan homogenitas pada kelas eksperimen dan kontrol sehingga diperoleh informasi bahwa kedua kelas tersebut homogen dan normal. Setelah itu, data hasil pre-test pada kelas eksperimen dan kontrol dianalisis dengan uji-t independent diperoleh informasi bahwa tidak ada perbedaan signifikan. Berarti, seluruh peserta didik berada pada kategori kurang/rendah dan memiliki kemampuan yang sama sebelum dilakukan pembelajaran, di mana rata-rata nilai hasil belajar peserta didik pada kelas eksperimen dan kontrol masing-masing adalah 51,74 dan 54,26 yang dapat dilihat pada Tabel 3.

Tabel 3 Rata-rata nilai pre-test dan post-test hasil belajar pengetahuan

\begin{tabular}{|c|c|c|c|c|}
\hline \multirow{2}{*}{ Nilai } & \multicolumn{2}{|c|}{ Nilai Kelas Eksperimen } & \multicolumn{2}{|c|}{ Nilai Kelas Kontrol } \\
\hline & pre-test & post-test & pre-test & post-test \\
\hline Terendah & 20 & 60 & 20 & 40 \\
\hline Tertinggi & 86,7 & 100 & 93,3 & 93,3 \\
\hline Rata-rata & 51,74 & 78,93 & 54,26 & 69,42 \\
\hline
\end{tabular}

Selanjutnya, hasil post-test peserta didik dianalisis statistik inferensial dengan uji-t independent pada kelas eksperimen dan kontrol sehingga diperoleh informasi bahwa ada perbedaan yang signifikan dengan nilai sig. sebesar $0,03<0,05$. Berarti, ada perbedaan capaian hasil belajar, di mana ratarata nilai hasil belajar peserta didik pada kelas eksperimen dan kontrol masing-masing 78,93 dan 69,42. Kelas eksperimen memiliki nilai rata-rata lebih tinggi dari pada kelas kontrol. Perbedaan ini karena adanya perbedaan strategi pembelajaran yang diterapkan. Kelas eksperimen menerapkan strategi REACT berbasis kontekstual dan berpusat pada peserta didik yang mampu melibatkan mereka secara aktif melalui tahap-tahapannya, sedangkan kelas kontrol menggunakan pembelajaran konvensional dengan metode ceramah dan diskusi.

Hasil uji paired sample t-test pada masing-masing kelas menunjukkan adanya perbedaan hasil post-test dengan pre-test hasil belajar peserta didik dengan nilai sig. sebesar $0,00<0,05$ pada kelas ekperimen dan kelas kontrol. Hal ini menandakan pada kelas eksperimen dan kontrol sama-sama mengalami peningkatan belajar. Kemudian perbandingan tingkat kualitas hasil belajar peserta didik pada kelas eksperimen dan kontrol dapat diketahui dengan menghitung $n$-gain kedua kelas dari hasil pretest dan post-test pada masing-masing kelas. Didapat hasil rata-rata $n$-gain pada kelas kontrol sebesar 0,3 dan termasuk dalam kategori rendah atau lemah. Sedangkan pada kelas eksperimen sebesar 0,6 dalam kategori sedang. Dengan demikian, strategi $R E A C T$ lebih efektif dalam meningkatkan hasil belajar. Hal ini didukung oleh hasil penelitian Rahmah dkk. (2018) bahwa strategi REACT efektif untuk meningkatkan kognisi dan metakognisi peserta didik. Selain itu, Fakhruriza \& Kartika (2015) menemukan bahwa strategi $R E A C T$ efektif untuk meningkatkan hasil belajar. Pada setiap tahapan, peserta didik selalu terlibat aktif dalam mengembangkan pengetahuannya. Pada fase pertama yaitu relating (mengaitkan), peserta didik mampu mengaitkan pengetahuan dasar tentang pencemaran lingkungan seperti pencemaran air, udara, dan tanah yang ada dalam lingkungan sekitar. Peserta didik mampu menyebutkan ciri-ciri pencemaran dengan contoh banyak sampah, air sungai warnanya tidak jernih dan lain-lain. Fase kedua experiencing (mengalami), peserta didik melakukan kegiatan lapangan, pengamatan dan eksperimen untuk mendapat data-data faktual tentang pencemaran lingkungan. Kemudian tahap applying, peserta didik membangun konsep dari data-data empiris, yaitu konsep pencemaran, zat cemar, dan dampak pencemaran. Selanjutnya di tahap cooperating, peserta didik 
belajar dalam konteks berbagi, merespon, dan berkomunikasi dengan peserta didik lainnya baik dalam kelompok maupun antar kelompok untuk membentuk pengetahuan prosedural seperti proses terjadinya pencemaran dan langkah dalam memberi solusi pencemaran. Proses cooperating ini juga terjadi pada tahap transferring, di mana peserta didik memberikan pengetahuannya pada yang lain. Implementasi strategi REACT berpengaruh positif terhadap hasil belajar peserta didik. Hal ini sejalan dengan Marlan (2017) bahwa strategi REACT sangat berpengaruh terhadap hasil ujian akhir peserta didik. Strategi ini sebagai implementasi dari pendekatan kontekstual yang mampu melibatkan peserta didik secara aktif melalui tahapan-tahapannya. Strategi REACT diyakini lebih efektif daripada strategi konvensional dalam meningkatkan prestasi belajar peserta didik (Putri, 2015). Oleh karena itu, strategi REACT mampu mengatasi permasalahan hasil belajar yang rendah menjadi lebih baik.

\section{Keterampilan Sosial Peserta Didik}

Data keterampilan sosial peserta didik diperoleh melalui observasi awal dan observasi akhir di masing-masing kelas yaitu pada kelas eksperimen dan kelas control. Data hasil pengamatan disajikan pada Tabel 4.

Tabel 4. Rata-rata skor keterampilan sosial

\begin{tabular}{ccccc}
\hline \multirow{2}{*}{ Skor } & \multicolumn{2}{c}{ Skor kelas eksperimen } & \multicolumn{2}{c}{ Skor kelas kontrol } \\
\cline { 2 - 5 } & Observasi awal & Observasi akhir & Observasi awal & Observasi akhir \\
\hline Terendah & 37,50 & 75,00 & 18,75 & 18,75 \\
Tertinggi & 68,75 & 100,00 & 37,50 & 43,75 \\
\hline Rata-rata & $\mathbf{5 3 , 2 5}$ & $\mathbf{8 7 , 5 0}$ & $\mathbf{3 0 , 6 0}$ & $\mathbf{3 3 , 1 9}$ \\
\hline
\end{tabular}

Berdasarkan Tabel 4, pada kelas eksperimen terdapat perbedaan keterampilan sosial peserta didik dari observasi awal dengan hasil observasi akhir, rata-rata skornya adalah 53,25 dan 87,5. Hal ini dibuktikan dengan uji inferensial uji urutan bertanda Wilcoxon dengan taraf signif-ikansi $(\alpha) 0,05$, diperoleh nilai sig. sebesar 0,00<0,05 (taraf signifikansi), maka H0 ditolak sehingga dapat dikatakan bahwa data observasi awal dan akhir keterampilan sosial peserta didik pada kelas eksperimen terdapat perbedaan yang signifikan artinya terjadi peningkatan keterampilan sosial peserta didik. Sebaliknya, pada kelas kontrol adalah tidak ada perbedaan ket-erampilan sosial peserta didik dari observasi awal dengan hasil observasi akhir, yang mana rata-rata skornya adalah 30,60 dan 33,19 . Hal ini dibuktikan dengan uji urutan bertanda Wilcoxon dengan $\alpha=0,05$, diperoleh harga Asymp.Sig sebesar 0,133. Hasil nilai sig. $>0,05$ (taraf signifikansi), maka H0 diterima sehingga dapat dikatakan bahwa data observasi awal dan akhir keterampilan sosial peserta didik pada kelas kontrol tidak terdapat perbedaan yang signifikan.

Setelah dibandingkan hasil keterampilan sosial peserta didik antara kelas eksperimen dan kontrol terdapat perbedaan yang signifikan yang dinyatakan hasil dari uji Kruskal-Wallis dengan taraf signifikansi ( $\alpha$ ) 0,05, diperoleh harga sig. sebesar $0,00<0,05$ (taraf signifikansi), maka H0 ditolak sehingga dapat dikatakan bahwa data observasi akhir keterampilan sosial peserta didik pada kelas eksperimen dan kontrol terdapat perbedaan yang signifikan. Perbedaan ini karena pada kelas eksperimen menerapkan strategi REACT sedangkan kelas control hanya mengunakan pembelajaran konvensional metode ceramah dan diskusi. Selain itu, pada tahap cooperating dalam $R E A C T$, yaitu pelaksanaan bekerja sama dalam kelompok dapat menerapkan pembelajaran kooperatif yang menekankan adanya kerja sama dalam kelompokkelompok belajar. Peserta didik dapat mengembangkan keterampilan sosialnya. Hal ini sesuai hasil penelitian Sarimaya (2013) bahwa pembelajaran kooperatif dapat meningkatan keterampilan sosial peserta didik. Dalam pembelajaran kooperatif, peserta didik dapat melatih setiap indikator keterampilan sosial seperti bekerja sama dalam tim menjalin komunikasi yang baik antar peserta didik dan mampu menyelesaikan masalah.

Penekanan keterampilan sosial peserta didik dalam pembelajaran strategi $R E A C T$ tampak di tahap cooperating dan tranfering. Tahap ini menjadikan perbedaan capaian keterampilan sosial antara kedua kelas sampel. Tahap cooperating, peserta didik diberikan sebuah permainan berkelompok. Peserta didik bekerja sama menyelesaikan masalah atau persoalan yang diberikan dalam permainannya. Indikator keterampilan sosial yang terdapat pada tahap ini adalah keterampilan membangun tim dan keterampilan menyelesaikan masalah. Selanjutya tahap transfering, peserta didik bertukar hasil antar kelompok dimana didalamnya terdapat interaksi antar peserta didik. Indikator keterampilan sosial yang terdapat pada tahap ini 
adalah keterampilan dasar interaksi dan keterampilan komunikasi. Berikut ini uraian hasil keterampilan sosial peserta didik pada setiap indikator.

a. Keterampilan dasar interaksi

Keterampilan dasar interaksi, peserta didik diminta untuk bisa memerhatikan orang yang sedang berbicara dan menggunakan kontak mata ketika berbicara. Berdasarkan hasil observasi pada kelas kontrol terdapat $65,52 \%$ pada kategori cukup dan 34,48\% kategori baik. Sedangkan hasil observasi akhir pada kelas eksperimen terdapat $12 \%$ pada kategori baik dan $88 \%$ pada kategori sangat baik. Hal ini karena peserta didik telah terlatih selama proses kegiatan transfering untuk mengasah keterampilan sosialnya khususnya indikator keterampilan dasar interaksi, di mana ketika membagi informasi yang telah diperolehnya pada kelompok lain, mereka melakukan kontak mata dan memperhatikan ketika temannya berbicara. Hal ini sesuai hasil temuan Nitami (2018) bahwa interaksi sosial dapat meningkat dengan kegiatan kelompok yang di dalamnya ada proses bertukar informasi.

\section{b. Keterampilan komunikasi}

Keterampilan komunikasi, peserta didik bisa mendengarkan dan berbicara secara bergiliran dengan lembut atau sopan. Hasil observasi pada kelas kontrol untuk hasil observasi akhir ada 31,03\% pada kategori kurang dan 68,97\% pada kategori cukup. Peserta didik hanya mendengar, mencatat, dan mengerjakan soal dan dapat menjelaskan ketika diminta untuk menjelaskan sehingga masih lemah untuk indikator keterampilan komunikasi pada kelas kontrol. Sedangkan hasil observasi akhir pada kelas eksperimen terdapat $24 \%$ pada kategori baik dan $76 \%$ pada kategori sangat baik. Hal ini karena peserta didik dituntut untuk bisa mengasah komunikasinya ketika memberikan penjelasan pada temannya atau sebaliknya sehingga indikator keterampilan komunikasi mereka terlatih dalam kegiatan kelompok. Hal ini didukung Wangsa dkk. (2017) bahwa keterampilan komunikasi dapat ditingkatkan melalui pembelajaran kooperatif.

\section{c. Keterampilan membangun tim atau kelompok}

Keterampilan membangun tim atau kelompok adalah keterampilan yang dapat muncul apabila dalam pembelajaran menerapakan pembelajaran kelompok. Peserta didik dilatih mengakomodasi pendapat teman dan saling menolong dalam kelompoknya. Hasil observasi akhir pada kelas eksperimen terdapat $68 \%$ pada kategori baik dan 32\% pada kategori sangat baik. Sedangkan pada kelas kontrol untuk hasil observasi akhir terdapat $17,24 \%$ pada kategori kurang dan $82,76 \%$ pada kategori cukup. Pada kelas kontrol, peserta didik tidak mengalami perubahan dari hasil observasi sebelumnya dengan observasi akhir bahkan sedikit mengalami penurunan. Hal ini terjadi karena pembelajaran bersifat monoton sehingga peserta didik tidak memunculkan suatu perubahan dalam bekerjasama di dalam sebuah kelompok dan masih bersifat individual. Sedangkan pada kelas eksperimen, peningkatan skor pada hasil observasi akhir untuk indikator keterampilan membangun tim dari hasil observasi sebelumnya terjadi karena dilakukan arahan pada peserta didik untuk berbagi tugasnya agar mereka memiliki kemampuan dalam menjalin kerjasama. Pembelajaran dengan permainan kooperatif dapat melatihkan keterampilan membangun tim peserta didik. Hal ini sesuai dengan hasil penelitian Maresha (2012) bahwa keterampilan kerjasama peserta didik dapat dilatih melalui kegiatan permainan kooperatif.

\section{d. Keterampilan menyelesaikan masalah}

Keterampilan menyelesaikan masalah dalam keterampilan sosial adalah bagaimana peserta didik peduli terhadap teman dalam tim, menaati kesepakatan dalam berbagi tugas agar menemukan jalan keluar dari permasalahan dengan keterampilan sosial yang dimiliki, permasalahan yang diberikan menunjang peserta didik saling berinteraksi antar individu maupun kelompok. Hasil observasi akhir pada kelas eksperimen terdapat $28 \%$ pada kategori cukup, $40 \%$ pada kategori baik, dan $32 \%$ pada kategori sangat baik. Sedangkan, pada kelas kontrol untuk hasil observasi akhir terdapat $41,38 \%$ pada kategori kurang, dan 58,62\% pada kategori cukup. Pada kelas control, peserta didik tidak mengalami perubahan dari hasil observasi sebelumnya dengan observasi akhir karena dalam pembelajaran dalam kelas kontrol tidak ada stimulus untuk memunculkan keterampilan menyelesaikan masalah.

Peningkatan skor pada hasil observasi akhir pada kelas eksperimen untuk indikator keterampilan menyelesaikan masalah dari hasil observasi sebelumnya terjadi karena dalam permainan terdapat interaksi sosial dalam satu kelompok dan mendorong timbulnya kompetisi dan kerjasama. Akan tetapi indikator keterampilan menyelesaikan masalah skor rata-ratanya lebih rendah dibanding 
Maulida, Syahmani, \& Sari. (2020). Implementasi Strategi REACT Terhadap Hasil Belajar dan Keterampilan Sosial Peserta Didik

indikator 1 dan 2 dan 3 karena kemampuan peserta didik meyelesaikan masalah dalam sebuah kelompok tidak merata pada seluruh peserta didik, karena dalam kelompok masih terdapat peserta didik yang kesulitan menyelesaikan permasalahan dalam kelompoknya. Hal ini didukung dengan hasil penelitian Fadhilah (2014) yang menyatakan bahwa dalam proses diskusi, peserta didik masih kesulitan mengungkapkan idenya terhadap penyelesaian masalah.

\section{SIMPULAN}

Hasil penelitian menunjukkan; (1) ada perbedaan hasil belajar yang signifikan antara peserta didik yang belajar materi pencemaran lingkungan menggunakan strategi REACT dengan peserta didik yang belajar menggunakan pembelajaran konvensional, (2) ada peningkatan hasil belajar yang signifikan peserta didik yang belajar materi pencemaran lingkungan setelah menggunakan strategi REACT dalam kategori sedang, (3) ada perbedaan keterampilan sosial yang signifikan antara peserta didik yang belajar materi pencemaran lingkungan menggunakan strategi $R E A C T$ dengan peserta didik yang belajar menggunakan pembelajaran konvensional, dan (4) ada peningkatan keterampilan sosial yang signifikan peserta didik yang belajar materi pencemaran lingkungan setalah menggunakan strategi $R E A C T$. Dengan demikian, implementasi strategi REACT berdampak signifikan terhadap hasil belajar dan keterampilan sosial peserta didik. Adapun saran untuk penelitian selanjutnya adalah; (1) strategi REACT dapat menjadi alternatif bagi guru untuk meningkatkan hasil belajar dan keterampilan sosial peserta didik dalam pembelajaran IPA, (2) pengelolaan waktu pembelajaran diupayakan lebih efektif dan efisien, dan (3) guru membimbing peserta didik dalam melatih keterampilan sosial dalam pembelajaran IPA.

\section{DAFTAR PUSTAKA}

Abidin, A. (2016). Meningkatkan Keterampilan Sosial melalui Model Cooperative Learning Tipe Time Token Arends. Skripsi. Bandung: Universitas Pendidikan Indonesia.

Cahyono, B. A. D., Sutarto., \& Mahardika, I. K. (2017). REACT Learning Strategi (Relating, Experiencing, Applying, Cooperating, Transfering) to Media of Physics Phenomenon on Process Skills of Science and Student Achievement in Physics Learning at SMA. Jurnal Edukasi, 4(3), 20-24.

Fadhilah, P \& Siti, M. (2014). Penerapan Pendekatan Pembelajaran Berbasis Masalah terhadap Aktivitas Peserta Didik pada Konsep Sistem Pernapasan Manusia. JESBIO, 3(5), 28-36.

Fahmi. (2014). Pendidikan Karakter Berbasis Akhlak Mulia Melalui Pengamalan Terhadap Al-Qur'an. Proceedings International Seminar on Character Education. FKIP Unlam Press.

Fahmi. (2016). Strategi Pembelajaran Contextual Teaching and Learning untuk Meningkatkan Keterampilan Berpikir Tingkat Tinggi. Prosiding Seminar Nasional Pendidikan IPA 2016. S2 IPA Unlam Press.

Fakhruriza, O \& Kartika, I. (2015). Keefektifan Model Pembelajaran Relating, Experiencing, Applying, Cooperating, Transfering (REACT) untuk Meningkatkan Hasil Belajar Peserta Didik SMP pada Materi Kalor. JRKPF UAD, 2(2), 54-57.

Hamdani. (2010). Startegi Belajar Mengajar. Bandung: CV Pusataka Setia

Ismawati, R. (2017). Strategi REACT dalam Pembelajaran Kimia SMA. Indonesian Journal of Science and Education, 1(1), 1-7.

Karsli, F \& Yigit, M. (2017). Effectiveness of The REACT Strategy on 12th Grade Students' Understanding of The Alkenes Concept. Research in Science \& Technological Education, 1(1), 118.

Kemendikbud. (2017). Panduan Penilaian oleh Pendidik dan Satuan Pendidikan untuk Sekolah Menengah Pertama. Jakarta: Kemendikbud.

Maresha, O. D \& Stanilasus, S. (2012). Keefektifan Permainan Kooperatif dalam Meningkatkan Keterampilan Sosial Anak Pra Sekolah. Jurnal Psikologi Ilmiah, 4(1), 1.

Marlan. (2017). The "REACT" Strategy Application in The Study of Mathematics. Asian Journal of Natural \& Applied Sciences, 6(4), 123-127.

Putri, R. I \& Santosa, R. H. (2015). Keefektifan Strategi REACT Ditinjau dari Prestasi Belajar, Kemampuan Penyelesaian Masalah, Koneksi Matematis, Self Efficacy. Jurnal Riset Pendidikan Matematika, 2(2), 262-272. 
Rahmah, S., Syahmani., \& Winarti, A. (2018). Validitas dan Praktikalitas Perangkat Pembelajaran Menggunakan Model Pembelajaran REACT Berbantuan Metacognitive Questioning untuk Meningkatkan Kognisi dan Keterampilan Metakognisi pada materi Larutan Elektrolit dan Non-elektrolit. In Proceeding Seminar: The Innovation of Chemistry Education in Confronting Disruption Era to Build Excellent and Productive Generation, 1(1), 159-167

Sarimaya, F. (2013). Peningkatan Keterampilan Sosial Peserta Didik SMP dalam Pembelajaran IPS melalui Pengembangan Model Pembelajaran Kooperatif. Tesis Pascasarjana UPI. Tidak Dipublikasikan.

Sugiarti \& Verianingsih. (2015). The Effect of Contextual Teaching and Learning (CTL) Approaches to The Study of Students in The Subject Matter of Additives and Addictive Substances in Class VIII SMPN 26 Makassar. Jurnal Chemica, 16(1), 47-55.

Suyidno \& Jamal, A. (2012). Startegi Belajar Mengajar. Banjarmasin: Nusamedia.

Syah, M. (2011). Psikologi Belajar. Jakarta: Bumi Aksara.

Thalib, S. B. (2010). Psikologi Pendidikan Berbasis Analisis Empiris Aplikatif. Yogyakarta: Kencana Media Group.

Utlay, A. (2012). Implementing REACT Strategy in A Context-Based Physics Class: Impulse and Momentum Example. Journal for Energy Education Science and Technology Part B, 4, 234.

Ultay, N \& Çalik, M. (2016). A Comparison of Different Teaching Designs of 'Acids and Bases' Subject. Eurasia Journal of Mathematics, Science \& Technology Education, 12 (1), 57-86.

Wangsa, P., Suyana, I., Amalia, L., \& Setiawan A. (2017). Upaya Meningkatkan Kemampuan Komunikasi dan Pemahaman Konsep Peserta Didik melalui Pembelajaran Inkuiri Berbatu Teknik TSTS. Jurnal Wahana Pendidikan Fisika, 2(2), 27-31. 
Maulida, Syahmani, \& Sari. (2020). Implementasi Strategi REACT Terhadap Hasil Belajar dan Keterampilan Sosial Peserta Didik 